\title{
Toxic effect of commercial formulations of neem oil, Azadirachta indica A. Juss., in pupae and adults of the sugarcane borer, Diatraea saccharalis F. (Lepidoptera: Crambidae)
}

\author{
Efeito tóxico de formulações comerciais de óleo de neem, \\ Azadirachta indica A. Juss., em pupas e adultos da broca da \\ cana-de-açúcar, Diatraea saccharalis F. (Lepidoptera: Crambidae)
}

\author{
Larissa Carla Lauer Schneider ${ }^{1 *}$, Camila Vieira da Silva ${ }^{2}$, Hélio Conte ${ }^{3}$
}

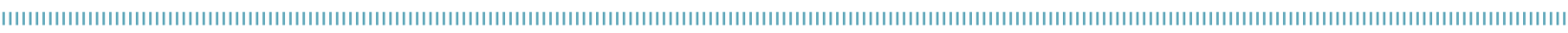

\begin{abstract}
To evaluate the toxic effect of commercial formulations of neem oil, Azadirachta indica A. Juss, pre-pupae (PP), young pupae (YP) and old pupae (OP) of Diatraea saccharalis F. (Lepidoptera: Crambidae) were sprayed with the diluted extract in distilled water at concentrations of 0.0 , $0.3,0.5,1.0$ and $2.0 \%$. The neem extract caused concentration-dependent effects on mortality of pupae, and the pupae that failed to emerge in adults had multiple abnormalities. The longevity of pupae that emerged in adults (YP and OP group) did not differ from the control group. The abnormalities found in adults were related to mortality in all treatments, except at the concentration of $1.0 \%$. Fertility was assessed according to the oviposition of adult females from the YP group that showed no abnormalities, through the evaluation of the number of deposited eggs and the rate of undeveloped eggs. The results showed a reduction in the number of eggs laid and an increase in the percentage of undeveloped eggs. These results show that neem oil has a high potential to control the toughest stage of the sugarcane borer and also reduces the further development. Therefore, commercial formulations of neem oil have a toxic effect on pupae and adults of $D$. saccharalis.
\end{abstract}

KEYWORDS: Neem oil extract; natural insecticide; sugarcane; toxicity.
RESUMO: Para avaliar o efeito tóxico de formulaçóes comerciais de óleo de neem, Azadirachta indica A. Juss, pré-pupas (PP), pupas jovens (PJ) e pupas velhas (PV) da Diatraea saccharalis F. (Lepidoptera: Crambidae) foram pulverizadas com o extrato diluído em água destilada, em concentraçóes de 0,0, 0,3, 0,5, 1,0 e 2,0\%. O neem provocou diferentes efeitos sobre a mortalidade de pupas, dependendo da concentraçáo. As pupas que não conseguiram emergir em adultos apresentaram anormalidades múltiplas. Quanto às pupas que emergiram em adultos (grupos PJ e PV), foi calculada a sua longevidade, que não diferiu da do grupo controle. As anormalidades encontradas em adultos estáo relacionadas com a mortalidade em todos os tratamentos com exceçâo da concentração de 1,0\%. A fecundidade foi avaliada de acordo com a oviposição de adultos fêmeas do grupo PJ, que não apresentaram anormalidades; dentro dos ovos depositados foi avaliado o número de ovos não desenvolvidos. Os resultados demonstraram redução no número de ovos depositados e aumento na porcentagem de ovos não desenvolvidos. Esses resultados mostraram que o óleo de neem tem elevado potencial para o controle do estágio mais resistente da broca da cana-de-açúcar, além de reduzir o aparecimento das fases subsequentes. Portanto, formulaçôes comerciais de óleo de neem apresentam um efeito tóxico em pupas e adultos de D. Saccharalis.

PALAVRAS-CHAVE: extrato oleoso de Neem; inseticida natural; cana-de-açúcar; toxicidade. 


\section{INTRODUCTION}

Azadirachta indica A. Juss., a plant in the Meliaceae family, popularly known as neem, has a total of 24 compounds with biological activities, including triterpenoids, phenols, carotenoids, steroids and ketones, which can be extracted from different parts of the tree (BISWAS et al., 2002). However, only four of these compounds have pesticide activities, including azadirachtin, solanine, melanthriol and nimbin (SCHMUTTERER, 1990; MORDUE (LUNTZ); BLACKWELL, 1993; HUANG et al., 1996).

The action of azadirachtin on pupae viability is variable according to the type of treatment, species and/or family of the insect, besides the applied dose. In most cases, the larval stage is the most sensitive to treatment. In pupae, however, because they are at a stage in which the insect does not feed and also because of a thicker cuticle layer, the action of insecticide products is less effective (KUMAR et al., 2005).

Studies with the direct application of neem on pre-pupae and pupae aiming to observe its action in these developmental stages are very rare. In Lepidoptera, especially, the majority of studies focuses on the immature stages of nymphs and caterpillars (SILVA et al., 2003; VIANA; PRATES, 2003; GREENBERG et al., 2005; GONÇALVEZ-GERVÁSIO; VENDRAMIN, 2007; NATHAN et al., 2007; KUMAR et al., 2012). EL-BOKL et al. (2010) analyzed the toxic effect of neem oil treatment in pre-pupae of Rhynchophorus ferrugineus Olivier (Coleoptera: Curculionidae).

The toxic effect of neem oil at various concentrations has been recently observed in eggs and subsequent stages of Diatraea saccharalis F. (Lepidoptera: Crambidae). This study demonstrated ovicidal and larvicidal effects in the first instars, with alterations in the embryonic development, impairing the formation of new individuals (SILVA et al., 2013). OLIVEIRA et al. (2013) also found alterations in D. saccharalis eggs, in which only $42.4 \%$ of caterpillars hatched and there was an extension of the embryonic period.

In order to seek natural alternatives that provide efficient control of the main pest of sugarcane in the stage less sensitive to insecticides, this study evaluated the effect of neem oil in pupal development and its residual effect on subsequent stages, especially the emergence and oviposition of adult D. saccharalis F. (Lepidoptera: Crambidae).

\section{METHODS}

\section{Effect of neem oil extract on pupal development}

To obtain the pre-pupae and pupae, larvae of $D$. saccharalis were placed on artificial diet (HENSLEY; HAMMOND JUNIOR, 1968) and maintained in controlled conditions of $25 \pm 1{ }^{\circ} \mathrm{C}$, relative humidity of $70 \pm 10 \%$ and photoperiod of 12 hours, at the Department of Cellular Biology and Genetics of the State University of Maringa, Paraná, Brazil. Pre-pupae and pupae of different ages were removed from the diet and separated into the following groups: pre-pupae (intermediate stage between caterpillars and pupae, beginning the melanization and chitinization); young pupae (one to six days of development); and old pupae (seven to fourteen days of development).

The bioinseticide used was NATUNEEM ${ }^{\circledast}$ (neem virgin oil with azadirachtin content above $1,500 \mathrm{ppm}$ ), an organic product certified by BCS OKO Garantie, Doc number Natur 9009/09.05/7331-BR. The neem oil extract was diluted in distilled water into the following concentrations: $0.0 ; 0.3 ; 0.5 ; 1.0$ and $2.0 \%$. Twelve individuals were used for each treatment, with three replicates for each concentration $(\mathrm{n}=36)$ and a total of 180 individuals per group. Approximately $100 \mu \mathrm{L}$ of the product was topically sprayed onto each organism.

After the treatments, all individuals were placed in polyethylene containers containing moistened cotton lined with filter paper and kept under the experimental conditions previously mentioned. Observations were made daily, up to 15 days after treatment, under a stereoscopic microscope (Zeiss). Abnormalities, mortality and longevity rates of the groups were recorded for later analysis.

\section{Residual effect of neem oil extract in stages subsequent to treatments}

The emergency rate, abnormalities and adult mortality for each treatment were evaluated in the three experimental groups during 15 days after treatment. Females that emerged from treated young pupae were separated into pairs and placed with two normal males in polyethylene boxes, lined with filter paper (posture chamber) and containing cotton soaked in sucrose solution, remaining incubated under experimental conditions for 48 hours. The experiment was repeated three times and the number of eggs deposited on the filter paper was quantified and compared to the number of the controls. The number of embryos that did not develop among the deposited eggs was also verified in relation to controls.

\section{Data analysis}

Experimental data from groups PP (pre-pupae), YP (young pupae) and OP (old pupae) were compared by analysis of variance (ANOVA). Results indicating differences between the values were analyzed by Tukey's multiple comparison test. In all cases, values of $\mathrm{p}<0.05$ were considered significant. The most frequent morphologic alterations found were documented photographically with a digital camera (Canon 7.0 MG) coupled to the stereoscopic microscope (Zeiss). 


\section{RESULTS AND DISCUSSION}

\section{Effect of neem oil extract on pupal development}

The treatment of pre-pupae and pupae of $D$. saccharalis of at different ages with neem oil extract caused differentiated and concentration-dependent mortality (Table 1). Similar results were found in pre-pupae of $R$. ferrugineus (Coleoptera: Curculionidae) and pupae of Corcyra cephalonica (Staint) (Lepidoptera: Pyralidae), in which mortality was higher, with increasing doses of topically applied extract (EL-BOKL et al. 2010; PATHAK; TIWARI, 2010).

According to Table 1 , at the concentrations of 0.3 and $0.5 \%$, the PP group was more susceptible to the product and was statistically different from other groups $(\mathrm{F}=19.44, \mathrm{df}=8$, $\mathrm{p}<0.01$ and $\mathrm{F}=39.92, \mathrm{df}=8, \mathrm{p}<0.01$, respectively). All groups differed statistically at the concentration of $1.0 \%(\mathrm{~F}=61.11$, $\mathrm{df}=8, \mathrm{p}<0.0001$ ), and the PP group did not differ statistically from the YP group at the $2.0 \%$ concentration, but both groups differed from the OP group $(\mathrm{F}=20.34, \mathrm{df}=8, \mathrm{p}<0.01)$.

TORRES et al. (2001) analyzed the effect of various aqueous plant extracts on the development of Plutella xylostella (Plutellidae), in which $A$. indica caused $100 \%$ mortality in caterpillars, not reaching the pupae stage. On the other hand, the topical application of neem oil extract and azadirachtin did not affect the survival of pupae of the predator Cycloneda sanginea (L.) (Coleoptera: Coccinellidae) (SILVA; MARTINEZ, 2004; COSME et al., 2007).

In this study, we observed that younger stages are more susceptible to neem treatment, as all treatments caused $100 \%$ mortality in the pre-pupae stage (Table 1). LADD et al. (1984) obtained similar results when azadirachtin was topically applied on pre-pupae and pupae of Popillia japonica (Coleoptera: Scarabaeidae) at different ages, in which the extract was effective in pre-pupae and one-day-old pupae, but had no effect on three-day-old ones.
Inhibition of ecdysis and consequent death of the pre-pupae can be attributed to the reduction of ecdysteroids peak or an interference in the release of the ecdysis hormone (SIEBER; REMBOLD, 1983). This may occur because azadirachtin has a structural formula similar to that of ecdysone, which can compete with this hormone and block its effect (NAKANISHI, 1975). Several studies described the anti-ecdysteroid action of azadirachtin, especially in the immature stages (SIEBER; REMBOLD, 1983; COUDRIET et al., 1985; ANDRADECOELHO et al., 2006; NATHAN et al., 2007).

In the present study, mortality was related to deformities of pre-pupae and pupae treated with neem (Table 1), in which morphologic alterations may be the cause of molt inhibition and death. All experimental groups differed at the concentration of $0.3 \%(\mathrm{~F}=496.0, \mathrm{df}=8, \mathrm{p}<0.0001)$, and the PP group was the most affected by the neem oil extract at $0.5 \%$, being different from the $\mathrm{YP}$ and $\mathrm{OP}$ groups $(\mathrm{F}=58.49, \mathrm{df}=8$, $\mathrm{p}<0.0001)$. In higher concentrations, the OP group was less affected by the treatment, differing from the other groups at the concentrations of $1.0 \%(\mathrm{~F}=16.0, \mathrm{df}=8, \mathrm{p}<0.01)$ and $2.0 \%(\mathrm{~F}=430.6, \mathrm{df}=8, \mathrm{p}<0.0001)$.

The most frequent abnormalities in pre-pupae, young pupae and old pupae are shown in Figure 1. After a few hours of treatment, it can be observed in the pre-pupae that the wings were free from the body and with changes in coloration, becoming darker. The abdomen remained lighter in color, typical of recent pre-pupae (Fig. 1A), indicating they did not continue the pupation process. There are several studies in the literature reporting the reduction of pupation after treatment with neem extracts in caterpillars, preventing the emergence of adults (KHAN et al., 2007; PATHAK; TIWARI, 2010; WAKIL et al., 2012).

In the young pupae, the most frequent abnormalities were abdominal deformations with the appearance of regions in which the cuticle remained thinner and with small black spots near the wing. In old pupae, increased melanization was

Table 1. Mean \pm standard error of the mortality rate and morphological alterations in pupae of different ages of $D$. saccharalis treated with neem oil extract in experimental conditions.

\begin{tabular}{|c|c|c|c|c|}
\hline \multirow{2}{*}{ Treatment (\%) } & \multicolumn{4}{|c|}{ Pupae age } \\
\hline & & PP & YP & OP \\
\hline \multirow{2}{*}{0.3} & MR & $100.0 \pm 0.0^{a}$ & $28.0 \pm 14.7^{b}$ & $17.0 \pm 9.8^{b}$ \\
\hline & MA & $100.0 \pm 0.0^{a}$ & $16.7 \pm 4.2^{b}$ & $0.0 \pm 0.0^{c}$ \\
\hline \multirow{2}{*}{0.5} & MR & $100.0 \pm 0.0^{a}$ & $61.3 \pm 5.7^{b}$ & $44.7 \pm 5.3^{b}$ \\
\hline & MA & $100.0 \pm 0.0^{a}$ & $47.3 \pm 5.1^{\mathrm{b}}$ & $39.0 \pm 5.5^{b}$ \\
\hline \multirow{2}{*}{1.0} & MR & $100.0 \pm 0.0^{a}$ & $72.67 \pm 5.7^{b}$ & $28.3 \pm 5.7^{c}$ \\
\hline & MA & $100.0 \pm 0.0^{a}$ & $100.0 \pm 0.0^{a}$ & $66.7 \pm 8.3^{b}$ \\
\hline \multirow{2}{*}{2.0} & MR & $100.0 \pm 0.0^{a}$ & $83.7 \pm 9.5^{a}$ & $44.7 \pm 5.3^{b}$ \\
\hline & MA & $100.0 \pm 0.0^{a}$ & $100.0 \pm 0.0^{a}$ & $44.7 \pm 2.7^{b}$ \\
\hline
\end{tabular}

MR: mortality rate; MA: morphological alterations; PP: pre-pupae; YP: young pupae; OP: old pupae; Means of each line followed by the same letter are not statistically different by the Tukey's test $(p>0.05)$. 
observed throughout the cuticle (Figs. 1B, 1C, 1D, 1E and 1F). Some reports in the literature also demonstrate abnormalities in pre-pupae and pupae, resulting from treatment with azadirachtin or neem oil, as in Spodoptera littoralis (Lepidoptera: Noctuidae) (MARTINEZ; EMDEN, 2001) and R. ferrugineus (BREAM et al., 2001).

These changes have also been reported in experiments performed on Bombyx mori larvae, suggesting some interference with ecdysteroid and juvenile hormone levels (KOUL et al., 1987; HORI et al., 1984). Another possible cause of the alterations in vital physiological events may be due to the water loss of the pupae. BREAM et al. (2001) found that desiccation increased proportionally to the neem extract dosage and to pupal mortality.

Because there was $100 \%$ mortality in the PP group, it was not possible to calculate the longevity at this stage, unlike the YP and OP groups, in which the means of longevity did not differ in relation to the control $(\mathrm{F}=0.47, \mathrm{df}=14$ and $\mathrm{p}>0.05$ in group $\mathrm{YP} ; \mathrm{F}=1.95, \mathrm{df}=14$ and $\mathrm{p}>0.05$ in group OP; Table 2). These results correspond to some studies that did not find any change in the duration of the pupae development period after larvae were treated with neem oil extracts (HERNANDEZ; VENDRAMIN, 1996; VENDRAMIN; SCAMPINI, 1997; TORRES et al., 2001).

\section{Residual effect of neem oil extract in stages subsequent to treatments}

The adult emergence rate is shown in Table 2. In the YP group, the rate decreased with increasing concentrations, with high statistical differences when comparing concentrations $(\mathrm{F}=35.53, \mathrm{df}=14, \mathrm{p}<0.0001)$. In the OP group, the statistical difference of the adult emergency rate was lower $(\mathrm{F}=9.63, \mathrm{df}=14, \mathrm{p}<0.01$; Table 2). Topical treatment of neem extract in $R$. ferrugineus pre-pupae resulted in reduced adult emergence rate, which exhibited various morphological abnormalities such as reduced body length (EL-BOKL et al., 2010). Topical treatment in Bactrocera cucurbitae (Coquillett) (Diptera: Tephritidae) and Ephestia cautella (Lepidoptera: Pyralidae) caterpillars also caused reduced adult emergence
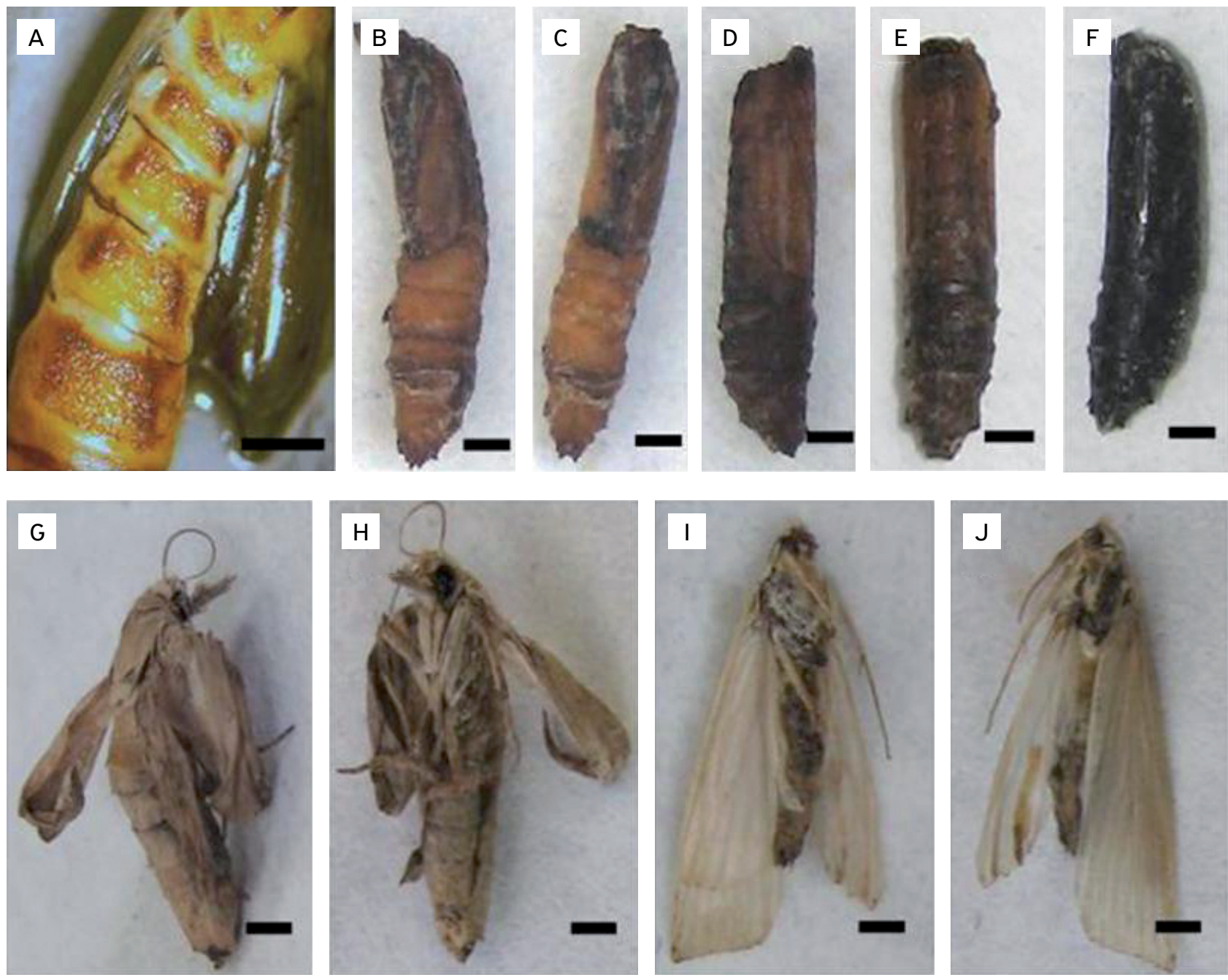

Figure 1. Morphological alterations caused by the neem oil extract (1.0 e 2.0\%) in pre-pupae after 24 hours of treatment (A); young pupae after 10 days of treatment (B-E); old pupae after 15 days of treatment (F); adults emerged from young pupae (G-H) and old pupae (I-J). 
rate (KHAN et al., 2007; SHEHU et al., 2010). Artificial diets containing different concentrations of the aqueous extract of $A$. indica also decreased the survival of $D$. saccharalis caterpillars (MAZZONETTO et al., 2013).

The percentage of abnormalities in adults is also described in Table 2. In the YP group, the abnormality rate was zero for both the $0.3 \%$ concentration and the controls, and at concentrations of 0.5 to $2.0 \%$, the rate was less than or equal to $50 \%$, in relation to the emergency rate $(\mathrm{F}=14.83$, $\mathrm{df}=14, \mathrm{p}<0.01)$. In the OP group, the abnormality rate in adults was rather variable, not being concentration-dependent $(\mathrm{F}=133.30, \mathrm{df}=14, \mathrm{p}<0.0001)$, which may be a result of morphogenetic alterations due to interferences in hormonal events (Figs. $1 \mathrm{G}$ and $1 \mathrm{H}$ ) (ALINIAZEE et al., 1997; GHONEIM et al., 2000).

SALLES; RECH (1999) observed that adults of Anastrepha fraterculus (Diptera: Tephritidae) resulting from treatment with neem had abnormal wings, which did not fully expand, characteristics also being described by LADD et al. (1984) and MARTINEZ; EMDEN (2001). Some adults of E. cautella also emerged deformed after treatment of the larvae with Calneem oil (SHEHU et al., 2010).

In the treatment of young pupae with higher concentrations of neem, some adults were unable to completely get rid of the exuvia, with some regions of the body remaining with parts of the old cuticle (pupa), such as wings, legs or abdomen (Figs. 1I and 1J). The occurrence of this fact, originating an intermediate pupa-adult, is a rare event. BREAM et al. (2001) reported no pupae-adult intermediates after neem treatment in $R$. ferrugineus pre-pupae, although they found this abnormality after the treatment of Culex pipiens larvae with Echinochloa stagninum (Poaceae) petroleum ether extract (BREAM et al., 2010). Intermediate larva-pupae were observed when the treatment with azadirachtin was applied in the last instar of the larva of Spodoptera litura, Spodoptera mauritia, Ephestia kuehniella, Manduca sexta and Spodoptera littoralis (GUJAR; MEHROTRA, 1983; JAGANNADH; NAIR, 1992; MARTINEZ; EMDEN, 2001).

The mortality rate in adults was increased with higher concentrations of neem $(\mathrm{F}=10.24, \mathrm{df}=14, \mathrm{p}<0.01$, Table 2$)$. In the experimental groups $\mathrm{YP}$ and $\mathrm{OP}$, adult mortality was related to the appearance of abnormalities, except at the concentration of $1.0 \%$ (Table 2). This fact can be explained due to the changes caused, being harmful to vital activities of the insect, such as locomotion, flight and, consequently, feeding (MARTINEZ; EMDEN, 2001).

The fecundity and viability of the eggs were analyzed by the oviposition of emerged females of the YP group that did not present abnormalities. The standard mean of the number of deposited eggs after the oviposition period, the number of undeveloped eggs and the percentage of undeveloped eggs were different in all treatments $(\mathrm{F}=2429, \mathrm{df}=14, \mathrm{p}<0.0001 ; \mathrm{F}=152.9 \mathrm{df}=14$, $\mathrm{p}<0.0001 ; \mathrm{F}=1247, \mathrm{df}=14, \mathrm{p}<0.0001$; Table 3). These results were similar to those of DAD et al. (2011), who observed reduced fecundity, limitation in the number of deposited eggs and totally inhibited eclosion after the treatment with neem in Musca domestica larvae.

Table 2. Mean \pm standard error of longevity, emergency rate, morphological abnormalities and mortality of adults emerged of young pupae and old pupae of $D$. saccharalis treated with neem oil extract in experimental conditions.

\begin{tabular}{lccccccc}
\multirow{2}{*}{ (\%) } & Age & \multicolumn{5}{c}{ Treatments (\%) } \\
\cline { 2 - 7 } & & 0.0 & 0.3 & 0.5 & 1.0 & 2.0 \\
LO & YP & $9.0 \pm 0.0^{\mathrm{a}}$ & $9.2 \pm 0.2^{\mathrm{a}}$ & $8.7 \pm 0.4^{\mathrm{a}}$ & $9.0 \pm 0.3^{\mathrm{a}}$ & $10.0 \pm 0.6^{\mathrm{a}}$ \\
\cline { 2 - 8 } & OP & $5.7 \pm 0.4^{\mathrm{b}}$ & $5.8 \pm 1.1^{\mathrm{b}}$ & $4.9 \pm 1.0^{\mathrm{b}}$ & $6.0 \pm 1.2^{\mathrm{b}}$ & $6.8 \pm 0.9^{\mathrm{b}}$ \\
\hline \multirow{2}{*}{ EM } & YP & $100.0 \pm 0.0^{\mathrm{a}}$ & $72.3 \pm 5.6^{\mathrm{a}}$ & $39.3 \pm 5.3^{\mathrm{b}}$ & $28.3 \pm 5.7^{\mathrm{b}}$ & $17.0 \pm 9.8^{\mathrm{b}}$ \\
\cline { 2 - 8 } & OP & $100.0 \pm 0.0^{\mathrm{a}}$ & $83.7 \pm 9.5^{\mathrm{a}}$ & $55.7 \pm 5.7^{\mathrm{b}}$ & $72.7 \pm 5.7^{\mathrm{b}}$ & $55.7 \pm 5.7^{\mathrm{b}}$ \\
\hline \multirow{2}{*}{ MA } & YP & $0.0 \pm 0.0^{\mathrm{a}}$ & $0.0 \pm 0.0^{\mathrm{a}}$ & $44.7 \pm 5.3^{\mathrm{b}}$ & $50.0 \pm 14.4^{\mathrm{b}}$ & $50.0 \pm 0.0^{\mathrm{b}}$ \\
\hline \multirow{2}{*}{ MO } & OP & $0.0 \pm 0.0^{\mathrm{a}}$ & $41.7 \pm 8.3^{\mathrm{b}}$ & $19.7 \pm 2.7^{\mathrm{c}}$ & $8.3 \pm 2.1^{\mathrm{d}}$ & $36.2 \pm 1.1^{\mathrm{b}}$ \\
\hline & YP & $0.0 \pm 0.0^{\mathrm{a}}$ & $0.0 \pm 0.0^{\mathrm{a}}$ & $14.4 \pm 1.9^{\mathrm{a}}$ & $0.0 \pm 0.0^{\mathrm{a}}$ & $33.3 \pm 8.3^{\mathrm{b}}$ \\
\hline & OP & $0.0 \pm 0.0^{\mathrm{a}}$ & $22.3 \pm 5.3^{\mathrm{ac}}$ & $33.3 \pm 8.3^{\mathrm{bc}}$ & $33.3 \pm 8.3^{\mathrm{bc}}$ & $55.7 \pm 5.7^{\mathrm{b}}$ \\
\hline
\end{tabular}

LO: longevity; EM: emergency rate; MA: morphological abnormalities; MO: mortality of adults; YP: young pupae; OP: old pupae; Means of each line followed by the same letter are not statistically different by the Tukey's test $(p>0.05)$.

Table 3. Mean \pm standard error of number of deposited eggs, number of undeveloped eggs and percentage of undeveloped eggs obtained from the oviposition of adult females emerged from young pupae of $D$. saccharalis treated with neem oil extract in experimental conditions.

\begin{tabular}{lccc} 
Treatments & Number of deposited eggs & Number of undeveloped eggs & $\%$ of undeveloped eggs \\
$0.0 \%$ & $3760.0 \pm 40.4^{\mathrm{a}}$ & $358.70 \pm 7.5^{\mathrm{a}}$ & $9.54 \pm 0.3^{\mathrm{a}}$ \\
\hline $0.3 \%$ & $1932.00 \pm 19.1^{\mathrm{b}}$ & $368.30 \pm 3.7^{\mathrm{a}}$ & $19.07 \pm 0.4^{\mathrm{b}}$ \\
\hline $0.5 \%$ & $1670.00 \pm 28.0^{\mathrm{c}}$ & $470.70 \pm 8.4^{\mathrm{b}}$ & $28.18 \pm 0.2^{\mathrm{c}}$ \\
\hline $1.0 \%$ & $546.30 \pm 33.5^{\mathrm{d}}$ & $250.00 \pm 8.6^{\mathrm{c}}$ & $45.90 \pm 1.2^{\mathrm{d}}$ \\
\hline $2.0 \%$ & $248.70 \pm 8.2^{\mathrm{e}}$ & $248.70 \pm 8.2^{\mathrm{c}}$ & $95.95 \pm 1.7^{\mathrm{e}}$ \\
\hline
\end{tabular}

Means of each line followed by the same letter are not statistically different by the Tukey's test $(p>0.05)$. 
Studies with azadirachtin or neem oil on Lepidoptera also demonstrated changes in fertility and fecundity of $S$. littoralis (PINEDA et al., 2009), anti-oviposition and ovicidal effects against $E$. cautella (SHEHU et al., 2010), ovicide with changes in the embryonic development against $D$. saccharalis (SILVA et al., 2013) and extended embryonic period in D. saccharalis (OLIVEIRA et al., 2013).

In this work, the fecundity of females from the YP group and the viability of deposited eggs decreased with higher doses of the neem extract, probably because azadirachtin inhibits oogenesis and the production of ecdysteroids (REMBOLD; SIEBER, 1981) synthesized by follicular cells during ovarian development and later incorporated into the eggs (GLASS et al., 1978). The inhibitory action of neem in vitellogenesis (DENARDI et al., 2011) and in the follicular cells by degeneration, hyperplasia and necrosis
(EL-BOKL et al., 2010) also justifies the reduction of fecundity and egg viability. KHAN et al. (2007) also observed inhibition in the ovarian development in adults of $B$. cucurbitae due to reduction of ovarian size after treatment with neem formulations.

\section{CONCLUSION}

The neem oil extract altered the pupae morphology and also modified the behavior of adults of $D$. saccharalis, consequently reducing the viability of each of these stages. Therefore, the neem extract proved to be an efficient control for the stage less sensitive to insecticides, interfering throughout the life cycle of the insect. REFERENCES

ALINIAZEE, M.T.; ALHUMEYRI, A.; SAEED, M. Laboratory and field evaluation of a neem insecticide against Archips rosanus $L$. (Lepidoptera: Tortricidae). The Canadian Entomologist, v.129, p.27-33, 1997.

ANDRADE-COELHO, C.A.; DE SOUZA, N.A.; FEDER, M.D.; DA SILVA, C.E.; GARCIA, E.S.; AZAMBUJA, P.; GONZALEZ, M.S.; RANGEL, E.F. Effects of Azadirachtin on the Development and Mortality of Lutzomyia longipalpis Larvae (Diptera: Psychodidae: Phlebotominae). Journal of Medical Entomology, v.43, p.262-266, 2006.

BISWAS, K.; CHATTOPADHYAY, I.; BANERJEE, R.K.; BANDYOPADHYAY, U. Biological activities and medicinal properties of neem (Azadirachta indica). Current Science, v.82, n. 11 , p.1336-1345, 2002

BREAM, A.S.; GHONEIM, K.S.; TANANI, M.A.; NASSAR, M.I. The disruptive effects of the azadirachtin and jojoba on development and morphologenesis of the red palm weevil Rhynchophorus ferrugineus (Curculionidae: Coleoptera). In: SECOND INTERNATIONAL CONFERENCEON DATE PALM, p.280-303, 2001.

BREAM, A.S.; EI-SHEIKH, T.M.; FOUDA, M.A.; HASSAN, M.I. Larvicidal and repellent activity of extracts derived from aquatic plant Echinochloa stagninum against Culexpipiens. Tunisian Journal of Plant Protection, v.5, p.107-123, 2010.

COSME, L.V.; CARVALHO, G.A.; MOURA, A.P. Efeitos de inseticidas botânicos e sintéticos sobre ovos e larvas de Cycloneda sanguinea (Linnaeus) (Coleoptera: Coccinellidae) em condições de laboratório. Arquivos do Instituto de Biologia, v.74, n.3, p.251-258, 2007.
COUDRIET, D.L.; PRABHAKER, N.; MEYERDIRK, D.E. Sweet Potato Whitefly (Homoptera: Aleyrodidae): Effects of Neem-seed Extract on Oviposition and Immature Stages. Environmental Entomology, v.14, p.776-779, 1985.

DAD, I.; YOUSUF, M.J.; ANJUM, S.I. Determination of LC ${ }_{50}$ of chlorpyrifos and neem extract on third instar larvae of house flies and their effect on fecundity. Journal of Basic and Applied Sciences, v.7, n.2, p.169-174, 2011.

DENARDI, S.E.; BECHARA, G.H.; OLIVEIRA, P.R.; MATHIAS, M.I.C. Inhibitory action of neem aqueous extract (Azadirachta indica $a$. Juss) on the vitellogenis of Rhipicephalus sanguineus (Latreille, 1806) (Acari: Ixodidae) ticks. Microscopy Research and Technique, v.74, n.10, p.889-899, 2011.

EL-BOKL, M.M.; BAKER, R.F.A.; EL-GAMMAL, H.L.; MAHMOUD, M.Z. Biological and histopathological effects of some insecticidal agents against red palm weevil Rhynchophorus ferrugineus. Egyptian Academic Journal of Biological Science, v.1, n. 1, p.7-22, 2010.

GHONEIM, K.S.; MOHAMED, H.A.; BREAM, A.S. Efficacy of the neem seed extract, Neemazal on growth and development of the Egyption Cotton Leafworm, Spodoptera littoralis (Bosid.) (Lepidoptera: Noctuidae). Journal of the Egyptian German Society of Zoology, v.33, p.161-179, 2000.

GLASS, H.; EMMERICH, H.; SPINDLER, K.D. Immunohistochemical localization of eckysterois in the follicular epithelium of locust oocyte. Celland Tissue Research, v.194, p.237-244, 1978. 
GONÇALVES-GERVÁSIO, R.C.R.; VENDRAMIN, J.D. Bioatividade do extrato aquoso de sementes de nim sobre Tuta absoluta (Meyrick, 1917) (Lepidoptera: Gelechiidae) em três formas de aplicação. Ciências Agrotécnicas, v.31, n.1, p.28-34, 2007.

GREENBERG, S.M.; SHOWLER, A.T.; LIU, T.X. Effects of neembased insecticides on beet armyworm (Lepidoptera: Noctuidae). Insect Science, v.12, n. 1, p.17-23, 2005.

GUJAR, G.T.; MEHROTRA, K.N. Juvenilizing effect of azadirachtin on a noctuid moth, Spodoptera litura Fabr. Indian Journal of Experimental Biology, v.21, p.292-293, 1983.

HENSLEY, S.D.; HAMMOND JUNIOR, A.M. Laboratory techniques for rearing the sugarcane bore ronan artificial diet. Journal Economical Entomology, v.61, p.1742-1743, 1968.

HERNANDEZ, C.R.; VENDRAMIN, J.D. Toxidad de extractos acuosos de Meliacea en Spodoptera frugiperda (Lepidoptera: Noctuidae). Manejo Integrado de Plagas, v.42, p.14-22, 1996.

HORI, M.; HIRUMA, K.; RIDDIFORD, L.M. Cuticular melanization in the tobacco Hornworm larvae. InsectBiochemistry, v. 14, p.267-274, 1984.

HUANG, R.C.; ZHOU, J.-B.; SUENAGA, H.; TAKEZAKI, K.; TADERA, K.; NAKATANI, M. Insect antifeeding property of limonoids from Okinawan and Chinese Melia azedarach L., and from Chinese Melia toosendan (Meliaceae). Bioscience, Biotechnology and Biochemistry, v.59, n.9, p.1755-1757, 1996.

JAGANNADH, V.; NAIR, V. Azadirachtin-induced effects on larval-pupal transformation of Spodoptera mauritia. Physiological Entomology, v.17, p.56-61, 1992.

KHAN, M.; HOSSAIN, M.A.; ISLAM, M.S. Effects of neem leaf and a commercial formulation of a neem compound on the longevity, fecundity and ovarian development of the melon fly Bactroceracucurbitae (Coquilett) and the oriental fruit fly, Bactroceradorsalis (Hendel) (Diptera: Tephritidae), Pakistan Journal of Biological Sciences, v. 10, n.20, p.3656-3661, 2007.

KOUL, O.; AMANAI, K.; OHTAKI, T. Effects of azadirachtin on the endocrine events of Bombyx mori. Journal of Insect Physiology, v.33, p.103-108, 1987.

KUMAR, P.; POEHLING, H.-M.; BORGEMEISTER, C. Effects of different application methods of azadirachtin against sweetpotato whitefly Bemisiatabaci Gennadius (Homoptera: Alyrodidae) on tomato plants. Journal of Applied Entomology, v. 129, p.483-497, 2005.

KUMAR, P.M.; MURUGAM, K.; KOVENDAN, K.; SUBRAMANIAM, J.; AMARESAN, D. Mosquito larvicidal and pupicidal efficacy of Solanum xanthocarpum (Family: Solanaceae) leaf extract and bacterial insecticide, Bacillus thuringiensis, against Culex quinquefasciatus Say (Diptera: Culicidae). Parasitology Research, v. 110, n.6, p.2541-2550, 2012.

LADD, T.L.; WARTHEN, J.D.; KLEIN, M.G. Japanese Beetle (Coleoptera: Scarabaeidae): the effects of Azaradirachtin on the Growth and Development of the Immature Forms. Journal of Economical Entomology, v.77, p.903-905, 1984.
MARTINEZ, S.S.; EMDEN, H.F.V. Growth Disruption, Abnormalities and Mortality of Spodoptera littoralis (Boisduval) (Lepidoptera: Noctuidae) Caused by Azadirachtin. Neotropical Entomology, v.30, p.113-125, 2001.

MAZZONETTO, F.; CORBANI, R.Z.; DALRI, A.B. Efeito de extratos aquosos de Azadirachta indica na sobrevivência de Diatraea saccharalis e na eclosão do parasitoide Cotesia flavipes. Revista Agrogeoambiental, v.5, n.2, p.83-90, 2013.

MORDUE (LUNTZ), A.J.; BLACKWELL, A. Azadirachtin: An update. Journal of Insect Physiology, v.39, p.903-924, 1993.

NAKANISHI, K. Structure of the insect antifeed ant azadirachtin. Recent Advances in Phytochemistry, v.9, p.283-298, 1975.

NATHAN, S.S.; CHOI, M.Y.; PAIK, C.H.; SEO, H.Y.; KIM, J.D.; KANG, S.M. The toxic effects of neem extract and azadirachtin on the brown planthopper, Nilaparvata lugens (Stal) (BPH) (Homoptera: Delphacidae). Chemosphere, v.67, p.80-88, 2007.

OLIVEIRA, H.N.; SANTANA, A.G.; ANTIGO, M.R. Atividade inseticida dos óleos de pinhão-manso (Jatropha curcas L.) e neem (Azadirachta indica A. Juss.) em ovos de Diatraea saccharalis (Fabr., 1794) (Lepidoptera: Crambidae). Arquivos do Instituto Biológico, v.80, n.2, p.229-232, 2013.

PATHAK, C.S.; TIWARI, S.K. Toxicological effects of nem Azadirachta indica A. Juss leaf powder against the ontogeny of Corcyra cephalonica (Staint.) (Lepidoptera: Pyralidae), Journal of Biopesticides, v.3, n.3, p.617-621, 2010.

PINEDA, S.; MARTINEZ, A.-M.; FIGUEROA, J.-I.; SCHNEIDER, M.-I.; DEL ESTAL, P.; VIÑUELA, E.; GÓMEZ, B.; SMAGGHE, G.; BUDIA, F. Influence of azadirachtin and methoxyfenozide on life parameters of Spodoptera littoralis (Lepidoptera: Noctuidae). Journal of Economic Entomology, v.102, n.4, p.1490-1496, 2009.

REMBOLD, H.; SIEBER, K.P. Inhibition of oogenesis and ovarian ecdysteroidsnthesis by azadirachtin in Locusta migratoria migratorioides (R. and F.). Zeitschrift für Naturforschung, v.36, p.466-469, 1981.

SALLES, L.A.; RECH, N.L. Efeito de extratos de Nim (Azadiracta indica) e cinamomo (Melia azedarach) sobre Anastrepha fraterculus (Wied.) (Diptera: Tephritidae). Revista Brasileira de Agrociência, v.5, p. 225-227, 1999.

SCHMUTTERER, H. Properties and potential of natural pesticides from the nem tree. Annual Review Entomology, v.35, p.271297, 1990.

SHEHU, A.; OBENG-OFORI, D.; EZIAH, V.Y. Biological efficacy of Calneem ${ }^{\mathrm{TM}}$ oil against the tropical warehouse moth Ephestia cautella (Lepidoptera: Pyralidae) in stored maize. International Journal of Tropical Insect Science, v.30, n.4, p.207-213, 2010.

SIEBER, K.-P.; REMBOLD, H. The effects of azadirachtin on the endocrine control of moulting in Locusta migratoria. Journal of Insect Physiology, v.29, p.523-527, 1983. 
SILVA, C.V.; SCHNEIDER, L.C.L.; CONTE, H. Toxicity and residual activity of a commercial formulation of oil from neem, Azadirachta indica A. Juss. (Meliaceae), in the embryonic development of Diatraea saccharalis F. (Lepidoptera: Crambidae). Journal of Biofertilizers \& Biopesticides, v.4, n. 1, p. 1-5, 2013.

SILVA, F.A.C.; MARTINEZ, S.S. Effect of Neem Seed Oil Aqueus Solutions on Survival and Development of the Predator Cycloneda sanguinea (L.) (Coleoptera: Coccinellidae). Neotropical Entomology, v.33, p.751-757, 2004.

SILVA, L.D.; BLEICHER, E.; ARAÚJO, A.C. Eficiência de azadiractina no controle de mosca-branca em meloeiro sob condições de casa de vegetação e campo. Horticultura Brasileira, v.2 1, n.2, p.198-201, 2003.

TORRES, A.L.; BARROS, R.; OLIVEIRA, J.V. Efeito de Extratos Aquosos de plantas no desenvolvimento de Putella xylostella (L.)
(Lepidoptera: Plutellidae). Neotropical Entomology, v.30, n.1, p.151-156, 2001.

VENDRAMIN, J.D.; SCAMPINI, P.J. Efeito do extrato aquoso de Melia azedarach sobre o desenvolvimento de Spodoptera frugiperda (J.E. Smith) em dois genótipos de milho. Revista de Agricultura, v.72, p.159-170, 1997.

VIANA, P.A.; PRATES, H.T. Desenvolvimento e mortalidade larval de Spodoptera frugiperda em folhas de milho tratadas com extrato aquoso de folhas de Azadirachta indica. Bragantia, v.62, p.69-74, 2003.

WAKIL, W.M.; GHAZANFAR, U.; NASIR, F.; QAYYUM, M.A.; TAHIR, M. Insecticidal efficacy of Azadirachta indica, nucleopolyhedrovirus and chlorantraniliprole singly or combined against field populations of Helicover paarmigera Hubner (Lepidoptera: Noctuidae). Chilean Journal of Agricultural Research, v.72, p.53-61, 2012. 